\title{
Fungi in Rice Straw, Cane Straw, Maize Straw and Their Potential as Decomposer
}

Ika Rochdjatun Sastrahidayat, Chintya Ivana Situmorang, Anton Muhibuddin

Majoring in Pests and Plant Diseases, Agroecotechnology Study Program, Agriculture Faculty of Brawijaya University

Correspondence Author : chintyasitumorang@yahoo.co.id/chintyasitumorang.cs@gmail.com

\begin{abstract}
Organic material decomposition is the reorganizing process of the organic material by microbes in the controlled circumstances. The microbes which were used in general such as fungi, bacteria or yeast. Aerobic yeasts is one of the microbes needs oxygen to work. Yeast was obtained by the exploration of the rice straw, maize straw and cane straw in Dau, Malang, East of Java. By the result of the microscopic exploration and observation through the microscope, it was obtained 9 yeast isolates and 3 fungi isolates. 2 yeast isolates and 1 fungi isolate from the rice straw, 2 yeast isolates and 1 fungi isolate from the maize straw, and 5 yeast isolates and 1 fungi isolate from the cane straw. The identification results were obtained Candida parapsilosis, Bellera oryzae, Kluyveromyces thermotolerant, Candida tropicalis, Debaryomyces hansenii, Wickerhamomyces anomalus, Pichia membranfaciens, Cryptococcus wieringae. The highest potential yeast as an organic fertilizer decomposer is Cryptococcus wieringae and the lowest is Bullera oryzae.
\end{abstract}

Keywords : Candida, Pichia, Cryptococcus, Bullera, Kluyveromyces, Debaryomyces Wickerhamomyces, Fusarium and Trichoderma 


\section{INTRODUCTION}

The organic material is needed to preserve the soil fertility by maintaining and improving the function of microorganisms in the soil to increase the availability of nutrients in the soil, and to enhance the fertilization effectiveness. Smith and Dougles (1967) mentioned the uses of organic fertilizer such as rice straw, maize straw, and cane straw along with inorganic fertilizer has expected to reduce the dosage of inorganic fertilizers. Some research results indicate the use of organic materials could increase the production of rice, maize, and cane (Watanabe et al., 2009; Djuniwati et al., 2003).

Agricultural waste in the form of straw is the local raw materials potential that be able to process be come organic fertilizer and compost. The utilization of straw in relation providing nutrients and organic material of soil is overhauling it into compost. The composting of straw naturally working by itself if the circumstances is ideal namely adequate water content (approximately 60\%) with the smooth aeration. Natural process of the straw composting approximately two weeks and three months. To accelerate the process of composting the straw be able to add with the composting activator (Distan, 2009).

Straw is an organic material which is available in the significant quantities for the farmers. Approximately $40 \% \mathrm{~N}, 30-35 \% \mathrm{P}, 80-85 \% \mathrm{~K}$, and $40-50 \% \mathrm{~S}$ steadfastly in the remaining of vegetative parts of the plant. Straw is also an important micronutrient sources such as zinc ( $\mathrm{Zn})$ and silicon (Si). Decomposition of organic material is the process of organic material reorganizing by microbes in the controlled circumstances. The soil organic material likewise contains nutrient sources in the type and amount variant depends on the origin material (Misra et al., 2003). The factors that affecting the decomposition process include aeration, moisture, $\mathrm{C} / \mathrm{N}, \mathrm{pH}$, temperature and the height of material accumulation, and raw material sizes. The microbes which were used in general such as fungi, bacteria or yeast. Yeast be able to work either oxidatively or fermentatively. In general, yeasts that work as a decomposer is aerobic yeasts. Aerobic yeast is one of the microbes that needs oxygen to work. Research on yeast has been done in many variations and types which were contained in the ecosystem of Indonesia. It proves that many of the yeasts in nature were exceed what we already know (Muhibuddin, A. And I. R. Sastrahidayat, 2005).

\section{METHODOLOGY}

This research was conducted in Pests and Plant Diseases Laboratory of Agriculture Faculty of Brawijaya University Malang in March - July 2017. The sampling of the rice straw is in Dau, Malang, East of Java. The sample analysis was conducted in Chemistry of the Soil Department. Microscopic knowledge was held in Biosciences of Brawijaya University.

\subsection{Tools}

The tools that used in this research namely basin, plastic tray, "Oxone" electric stove, "Duran" petri bowl, "Duran" medium bottle $250 \mathrm{ml}$, "Pyrex" measuring cup, "Duran" erlenmeyer tube $250 \mathrm{ml}$, "Pyrex" beaker glass $1000 \mathrm{ml}$, object glass, glass cover 18 x $18 \mathrm{~mm}$ size, drop pipette, "Vitlab" micro-pipette, ose needle, "Ohaus" weigher, "Iwaki" reaction tube, reaction tube shelf, spatula, bunsen, saucepan, cutter, scissor, lighters,"Olympus BX 41" microscope, Scanning Electron Microscope (SEM), handsprayer, "Allmerican" autoclave, "Protech model 722" rotary shaker, Laminar Air Flow Cabinet (LAFC), "Pyrex" dilution pump 100 ml, centrifuge, pH meter, UC 1000 bottle.

\subsection{Materials}

The tools were used in this research namely basin, plastic tray, "Oxone" electric stove, "Duran" petri bowl, "Duran" medium bottle 250ml, "Pyrex" measuring cup, "Duran" erlenmeyer tube $250 \mathrm{ml}$, "Pyrex" beaker glass $1000 \mathrm{ml}$, object glass, glass cover $18 \times 18 \mathrm{~mm}$ size, drop pipette, "Vitlab" micro-pipette, ose needle, "Ohaus" weigher, "Iwaki" reaction tube, reaction tube shelf, spatula, bunsen, saucepan, cutter, scissor, lighters,"Olympus BX 41" microscope, Scanning Electron Microscope (SEM), handsprayer, "Allmerican" autoclave, "Protech model 722" rotary 
shaker, Laminar Air Flow Cabinet (LAFC), "Pyrex" dilution pump 100 ml, centrifuge, pH meter, UC 1000 bottle.

\subsection{The ways of working}

\subsubsection{Test and Isolation Media Making}

The yeast exploration media is by using Potato Dextrose Agar (PDA) for Yeast Ekstrak Pepton Dextrose (YEPD). Yeast Ekstrak Pepton Dextrose's PDA belong to selective medium for the yeast species to make $1000 \mathrm{ml}$ of YEPD medium, required 2 grams of glucose, 5 grams of peptone, 10 grams of yeast extract powder, 20 grams of dextrose, 15 grams of PDA, $1000 \mathrm{ml}$ of aquadest and 2 choloropenicol capsules. The ways of making media doing by means boiled the aquadest with all the materials except the PDA and choloropenicol. The PDA inserted after the water boiled and stirred until evenly then added choloropenicol. The medium need to insert in to the medium bottle and sterilized by using autoclaf in $121^{\circ} \mathrm{C}$ and 2 atm pressure for 15 minutes. Furthermore the YEPD's PDA for $1517 \mathrm{ml}$ poured into a petri dish. Incubate for 24 hours at room temperature (Rehman, 2009).

The test medium of yeast growth in liquid medium a used with SB (Saboroud Broth) medium that required 10 grams of dextrus and 20 grams of pepton dissolved in 1 liter of sterile aquadest, the solution was heated until boiled and the material dissolved perfectly. The homogenized medium inserted to a medium bottle, sterilized by using the autoclaf in $121^{\circ} \mathrm{C}$ and 2 atm pressure for 15 minutes.

\subsubsection{The Yeast Exploration In Straw 1. Yeast and Fungi Isolation \\ 1. Yeast and Fungi Isolation}

The yeast isolation doing by means washing the whole plant, furthermore cutting the base of the stem and taking the leaves intact. The isolation method used is washing method, namely by soaking the base of stem and the clove leaves inserted into $100 \mathrm{ml}$ sterile aquades for base of stem and $200 \mathrm{ml}$ for leaf. Then shaken with a speed of $120 \mathrm{rpm}$ for 24 hours. The base of stem and leaves water immersion diluted by 10-3, 10-4 series, and 10-5 that were taken $50 \mathrm{pml}$, dispersed by spread plate method on YMA (Yeast Malt Agar) medium and awaited for 2-3 days to be purification. (Muhibuddin et al., 2015).

The fungi isolation doing by means washing the roots, stem, and leaves with the alcohol and aquades to sterilize the outer fungi so that the growing fungi is expected to arise from within the plant tissue. Then the sample is cut along $\pm 1 \mathrm{~cm}$. The sample pieces were sterilized by washing into $10 \% \mathrm{NaOCl}$ solution for 1 minute and then $96 \%$ alcohol soaked for 1 minute and repeated 2 times. Furthermore rinsed by aquades for 1 minute and repeated 2 times, then the sample pieces dried over sterile tissue. After dry, the sample pieces were planted in the PDA medium in the petri dish. The isolates were incubated for $5-7$ days at $25-30^{\circ} \mathrm{C}$ or until the endophytic fungi isolates growing to fill the petri dish(Muhibuddin et al., 2011). The observations done in 2 days once during the endophytic fungi appear to grow.

\section{Variety Index Calculation}

Variety Index Calculation aim to know the yeast variety which potentially developing as decomposer of the organic fertilizer from the rice straw by variety index calculation with the formula of (Ludwig and Reynold, 1988):

s

$$
\mathrm{H}^{\prime}=\sum\left(\frac{n i}{N}\right) \ln \left(\frac{n i}{N}\right)
$$

$i=1$

ISSN Print $\quad$ : 1979-7141 
Explanation:

$\mathrm{H}^{\prime}=$ Shannon Variety Index

$\mathrm{S}=$ Amount of Spesies

$\mathrm{ni}=$ Amount of the 1st type in all samples

$\mathrm{N}=$ The number of individuals of all types

Table 1. The Variety Index Explanation

\begin{tabular}{ll}
\hline$\underline{\left(H^{\prime}\right) \text { Variety Value }}$ & Criteria \\
\hline$\underline{H^{\prime}<1,0}$ & $\underline{\text { Low variety, dispersal of individuals quantities of each species are }}$ \\
\hline$\underline{1,0<H^{\wedge} 3,0}$ & $\underline{\text { Med }}$ \\
& $\underline{\text { Medium variety, dispersal of individuals quantities of each species }}$ \\
\hline$\underline{H^{\prime}>3,0}$ & $\underline{\text { High variety, dispersal of individuals quantities of each species are }}$ \\
& high \\
\hline
\end{tabular}

\section{Purification}

The yeast that has grown then purified by the method of petri dish dividing. The ose needle was sterilized using a spirtus burner while scratching from one quadrant to another. Furthermore, the medium was incubated at room temperature in reverse condition. The repetition of this purification doing three times until a single colony was obtained, the colony was then used as a stock culture (Benson, 2001).

\section{Identification}

The identification process doing by looking at the invisibility of a single yeast colony macroscopically and microscopically. The macroscopic identification doing by direct observing the appearance of yeast colonies on YEPD medium including shape, color, type of foliage, texture, edges, and elevation of the colony, presence or absence of hyphae (psedohifa) (Widrastutik et al., 2014 in Muhibuddin, 2016). The microscopic identification process of yeast- Microscopic observation was done in two ways namely placing the colonies on preparate. The single colony is placed on glass object with a little medium. After that closed by using the glass cover then squash and incubated for 24 hours in moist conditions. After 24 hours the colony on the preparate is ready to be observed in a microscope with 400 times magnification.

Microscopic identification doing by observing the appearance of colonies based on: shape and size of cell, sexual and asexual reproduction type, pattern of reproduction, and the existence of pseudohifa. The second is by Scanning Electron Microscope by means of centrifuge the yeast isolate at $2000 \mathrm{~g}$ for 10 minutes with $40 \mathrm{c}$ temperature then idle until the precipitate fused at the bottom then the supernatant (liquid) removed and precipitate washed 2 times by physiological $\mathrm{NaCl}$ after that resuspension with 3\% of gluteraldehyde with a ratio of 1: 1 then idle for 12 hours at the room temperature and washed 3 times by PBS for 15 minutes, make intake on coversilde and dehydrated ethanol $(30,50,70,80,90,100 \%)$ each 5 minutes then dried and coating with gold for 15 seconds, $20 \mathrm{~nm}$ and finally observed by SEM. The yeast identification is used by The Yeast 5 th Editions and other literature.

\subsubsection{Oxidative and Fermentative Test}

The yeast growth test in liquid medium has intended to find out the way working of the yeast which is fermentative or oxidative in SB liquid medium. The test doing by growing the yeast on the SB medium. As many one colony ose from the YEPD medium inserted into $10 \mathrm{ml} \mathrm{SB}$ medium and grown for $1 \times 24$ hours. The oxidative yeast in the SB medium will form a layer (film) or the pellicle on the surface of the medium, while the fermentative yeast will form the pellicle at the base of the medium, the strong oxidative yeast capable of fermentative action, characterized by the film layer and the precipitate in the liquid medium (Jumiyati et al, 2012). 


\subsubsection{Yeast Suspension}

Suspended aseptic production as much as one ose of yeast isolate aged 24 hours was inoculated in $10 \mathrm{ml}$ of SB medium, then incubated at room temperature for 1 x 24 hours. Furthermore, the mass equation $(\mathrm{OD}=1)$ using a spectrophotometer with wavelength $600 \mathrm{~nm}$.

\subsubsection{Yeast Isolate Test as the Organic Fertilizer Decomposer}

Suspended yeasts would reveal the difference between the oxidative yeast and the fermentative yeast. The rice straw in the terrain is moved in to several boxes according to the number of yeasts that had found. The yeast which is moved into the box $(10 \mathrm{~cm} \mathrm{x} 10 \mathrm{~cm})$ is an oxidative yeast. In advance of the yeasts inoculation, thing to be considered is to analyze the initial nutrients that contained in origin rice straw without the yeast inoculation. Subsequent to inoculation within 30 days, the nutrient analysis of nutrient analyzes was performed to determine the nutrient enhancement. The isolates yeast test as organic fertilizer decomposer is to determine which yeast has the highest potential to increase the rice straw biomass. The yeast which working well on the decomposition of rice straw, cane straw, and maize straw be able to change the physical shape of the straw itself.

\subsection{Data Analysis}

The data in this research is arranged by providing the yeast data as the exploration result descriptively

\section{RESULTS AND DISCUSSION}

\subsection{Yeast Isolation Of the Straw}

The yeast isolation result of straw was obtained 9 yeast isolates. From the rice straw was obtained 2 yeast isolates, maize straw obtained 2 yeast isolates and from cane straw was obtained 5 yeast isolates.

\section{1. $J P_{1} P^{\prime \prime}$ Candida parapsilosis}
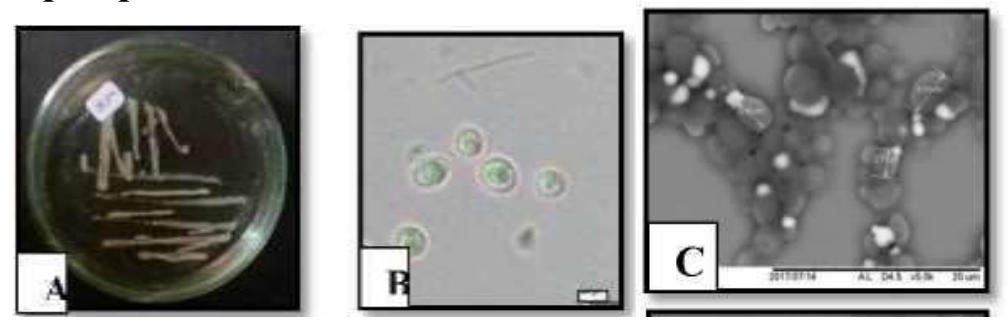

\section{MACROSCOPIC.}

Based on the macroscopic observations showing the beige colored colony, the elevation arise (convex), has a smooth texture, a shiny surface, and a flat colony edge. There is a pellicle or a ring layer on the surface of the liquid medium. This yeast could not conduct the fermentation process and alive at the high temperature (thermophilic).

\section{MICROSCOPIC.}

Based on the microscopic observations the size of C.anatomiae reaches $3.40 \mathrm{pm}$ visible and it is a single and paired cell. According to Langeron and Tallice (1932) the yeast growth in solid medium grows 1 day up to 3 days after inoculation. The cell length of C.anatomiae is $3-4 \times 5-8 \mathrm{pm}$. C.parapsilosis is single-celled and has short chain ties. Subsequent to 7 days at $25^{\circ} \mathrm{C}$ pseudohyphae (pseudo-hifa) was formed on the chain. 


\section{2. $\mathrm{JP}_{2} \mathrm{P}$ " Candidafloricola}
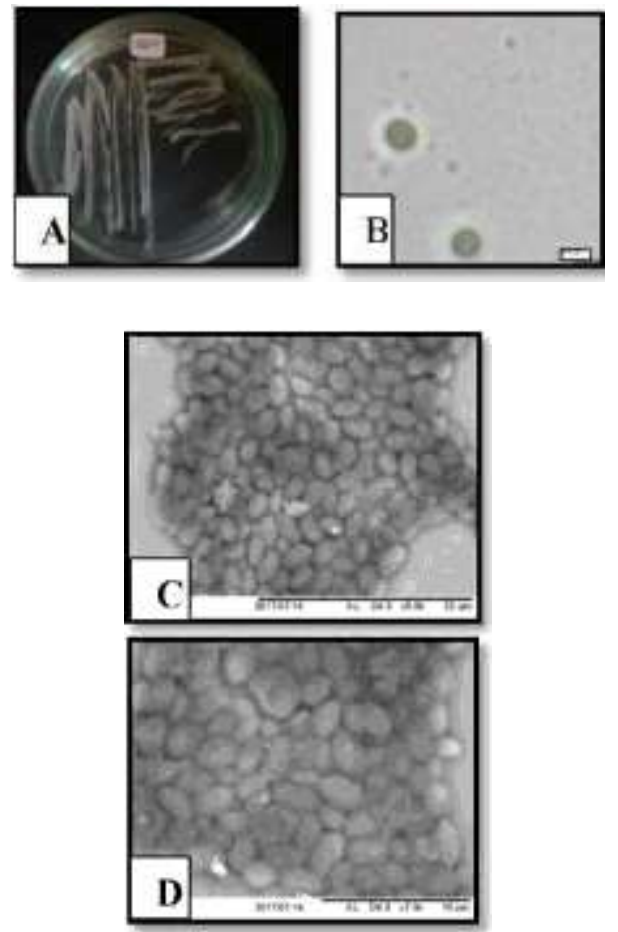

Figure 2. A) The growth of yeasts in the YEPD solid media. B) The microscopic appearance of yeast in the electron microscope by 800 times magnification. C) microscopic appearance of yeast in SEM by 5000 times magnification. D) microscopic appearance of yeast in SEM by 7000 times magnification.

\section{MACROSCOPIC}

Based on the macroscopic observations indicate the beige color colony, convex elevation, has a grain texture, a glossy surface, and a flat colony edge. In liquid medium, B. oryzae is aerobic caused by the liquid medium shall form a film layer or pellicle.

\section{MICROSCOPIC.}

Based on the microscope observation the size of B. oryzae reaches 2.0 to $3.47 \mathrm{pm}$ and has single cell and several of them have seen in pairs. According to Nakase and suzuki (1985c) subsequent to a week at $25{ }^{\circ} \mathrm{C}$ temperature the cells will grow in eggshaped with length size times width $58 \times 3.8$ $5 \mathrm{pm}$. The single cells will be in pairs. In this yeast the pseudohypae is not formed. This yeast is often encountered on the grass, rice, bamboo, and Chinese grass surface.

\section{3. $J_{1} P^{\prime \prime}$ Kluyveromyces thermotolerant}
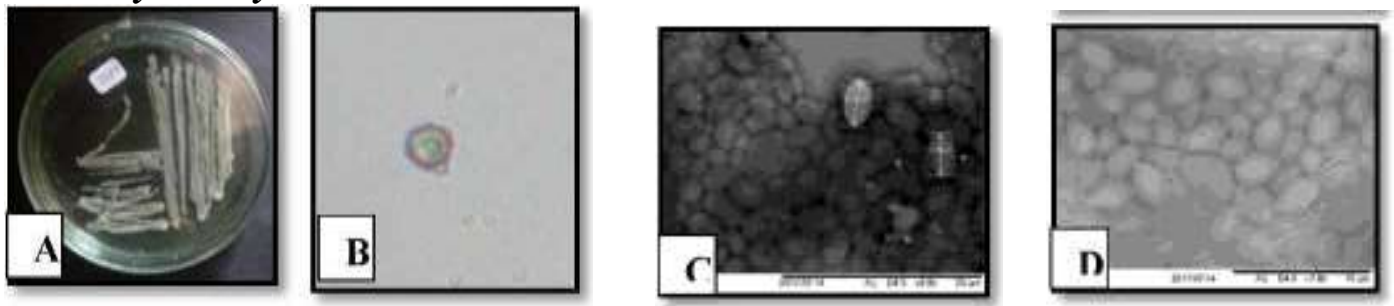

Figure 3. A) The growth of yeast in the YEPD solid media. B) The microscopic appearance of yeast in the electron microscope by 400 times magnification. C) microscopic appearance of yeast in SEM by 5000 times magnification. D) microscopic appearance of yeast in SEM by 7000 times magnification. 


\section{MACROSCOPIC.}

Based on the macroscopic observation indicate the white turn to beige color colony, convex elevation, has a smooth texture, a glossy surface, and a flat colony edge. In the liquid medium, $K$. thermotolerant is aerobic caused by the liquid medium will form a film layer or pellicle.

\section{MICROSCOPIC.}

Based on the microscopic observation indicate the size of $K$. thermotolerant 4,20 pm. Boulton (1996) subsequent to 3 days at $25{ }^{\circ} \mathrm{C}$ temperature the cells will grow in egg-shaped with length size times width in $.3 \times 3-4,5 \mathrm{pm}$. The single cells will be in pairs. This yeast reproduces by the multilateral budding. This yeast might found in fruits and it is widespread in the nature.

\section{4. $J_{2} \boldsymbol{P}{ }^{\prime \prime}$ Candida tropicalis}
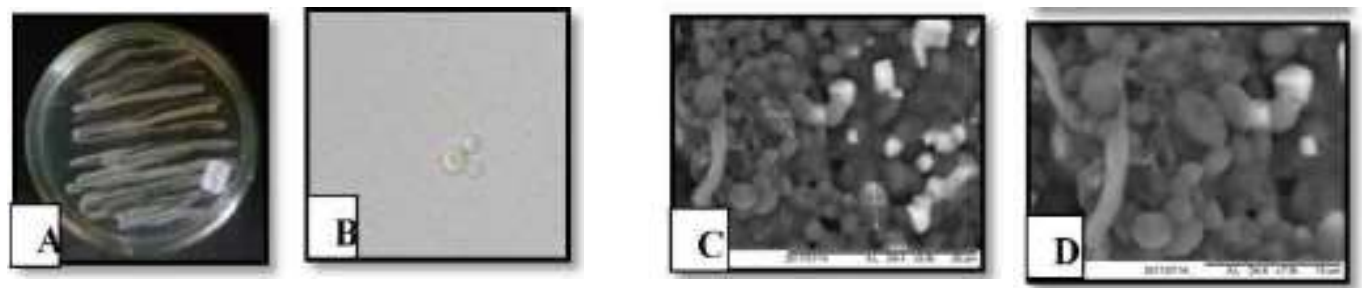

Figure 4. A) The growth of yeast in the YEPD solid medium. B) The microscopic appearance of yeast in the electron microscope by 400 times magnification. C) microscopic appearance of yeast in SEM by 5000 times magnification. D) microscopic appearance of yeast in SEM by 7000 times magnification.

\section{MACROSCOPIC.}

Based on the macroscopic observation indicate the beige color colony, convex elevation, has a smooth texture, a glossy surface, and a flat colony edge. In the liquid medium, C. tropicalis is aerobic caused by in the liquid medium sediment at the bottom and the film will visible or pellicle layer at the top and sometimes appear as a bubble.

\section{MICROSCOPIC.}

Based on the microscopic observation indicate the size of $C$. tropicalis $4,72 \mathrm{pm}$. there is a round and oval shape, there is no pseudo-hifa. It appears as the branching has a function as the budding for reproduction. According to Berkhout (1928) the cells has ellipsoid and pseudohyphae shape on PDA. Cell size is $3.0-5.5 \times 4.0-9.0 \mathrm{pm}$. This yeast might be found widespread in the nature such as in water, soil, leaves, and flowers.

\section{JT1P"s Debarymyces hansenii}
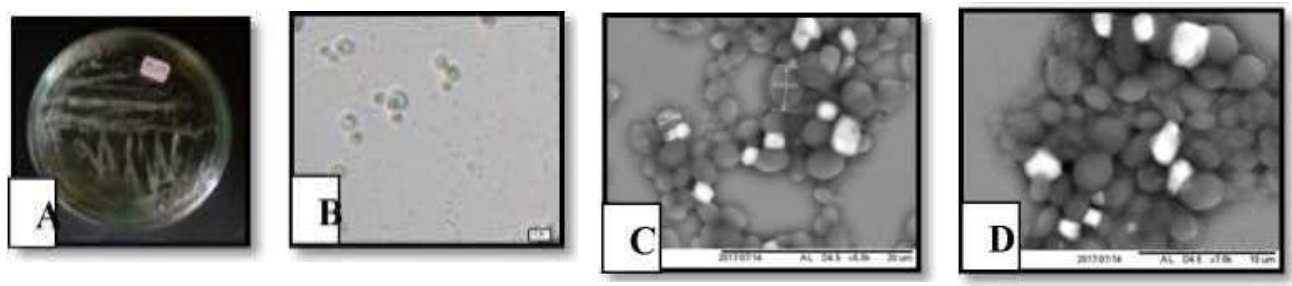

Figure 5. A) The growth of yeast in the YEPD solid media. B) The microscopic appearance of yeast in the electron microscope by 400 times magnification. C) microscopic appearance of yeast in SEM by 5000 times magnification. D) microscopic appearance of yeast in SEM by 7000 times magnification. 


\section{MACROSKOPIC.}

Based on the macroscopic observation indicate the tanish-white to beige, convex elevation, has a smooth texture, a glossy surface, and corrugated but generally flat edges. In the liquid medium a $D$. hansenii is aerobic caused by in liquid medium will form film layer or pellicle.

\section{MICROSKOPIC.}

Based on the the microscopic observation indicate $D$. hansenii has a size of 2.40 to $4.67 \mathrm{gm}$, a single cell and several of them seen in pairs. According to Lodder and Kreger Van Rij (1952) $D$. Hansenii has globose or subglobose shape measuring 2-7 x 2-9 gm. D. Hansenii has single cell in general or paired and forming short chain bonds. This yeast reproduces by the multilateral budding. This yeast might be found in the root area and in the soil.

\section{JT2P"2 Candida allociferrii}
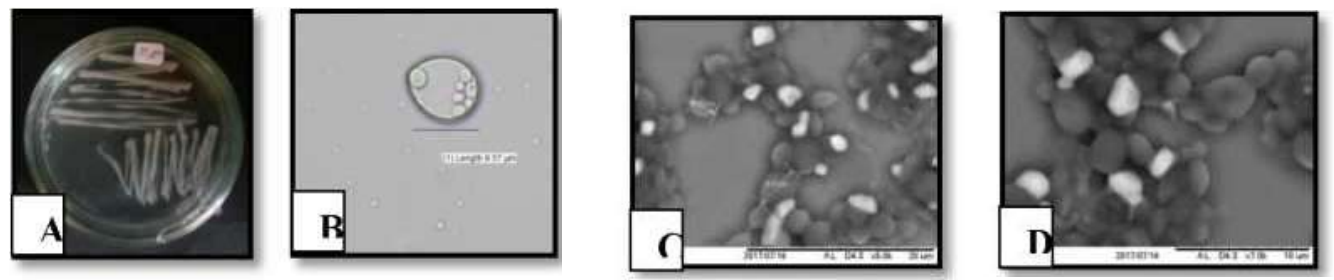

Figure 6. A) The growth of yeast in the YEPD solid media. B) The microscopic appearance of yeast in the electron microscope by 400 times magnification. C) microscopic appearance of yeast in SEM by 5000 times magnification. D) microscopic appearance of yeast in SEM by 7000 times magnification.

\section{MACROSKOPIC.}

Based on the macroscopic observation indicate the colony in tanish-white to beige, convex elevation, has a smooth texture, a glossy surface, and corrugated but generally flat edges. $D$. hansenii is aerobic caused by in liquid medium will form film layer or pellicle

\section{MICROSKOPIC.}

Based on the microscopic appearance of $D$. hansenii has a size of 2.40 to $4.67 \mathrm{pm}$, has a single cell and several of them seen oval in pairs. According to Lodder and Kreger Van Rij (1952) D. Hansenii has globose or subglobose shape measuring 2-7 x 2-9 pm. D. hansenii has single cell in general or paired and forming short chain bonds. This yeast reproduces by the multilateral budding. This yeast is found in the roots and on the ground.

\section{MACROSCOPIC.}

Based on the macroscopic observation indicate the tanish-white colony to beige, convex elevation, has a grain texture, a glossy surface, a flat colony edge. In liquid medium $W$. anomalus is aerobic caused by in liquid medium will form film layer or pellicle.

\section{JT2'P"2 Wickerhamomyces anomalus}
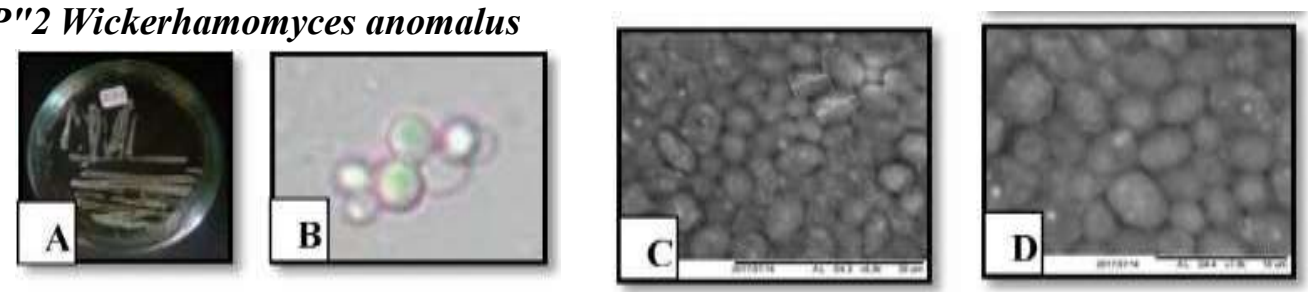

Figure 7. A) The growth of yeast in the YEPD solid media. B) The microscopic appearance of yeast in the electron microscope by 400 times magnification. C) microscopic appearance of yeast in SEM by 5000 times magnification. D) microscopic appearance of yeast in SEM by 7000 times magnification. 


\section{MACROSCOPIC.}

Based on the macroscopic observation indicate the tanish-white colony to beige, convex elevation, has a grain texture, a glossy surface, a flat colony edge. In liquid medium $W$. anomalus is aerobic caused by in liquid medium will form film layer or pellicle.

\section{MICROSKOPIC.}

Based on the microscopic appearance of $\mathrm{W}$. anomalus has a size of 3,8 pm the cell is round-egg shaped. The cell is single sometimes in pairs. According to Kurtzman (2008) subsequent to 3 days of inoculation at $25 \mathrm{oC}$, the cell will have globose or sub-globose shape and slowly turn into oval as egg-shape with size of 1.9-4.1 x 2,1- 6,1 pm. Cell is single or paired in general. According to Slavikova et al., 2007 the main habitat of this yeast is widespread in the nature, especially in soil and plant litter.Reproduction is by the multilateral budding.

\section{JT3P"2 Pichia chilensis}
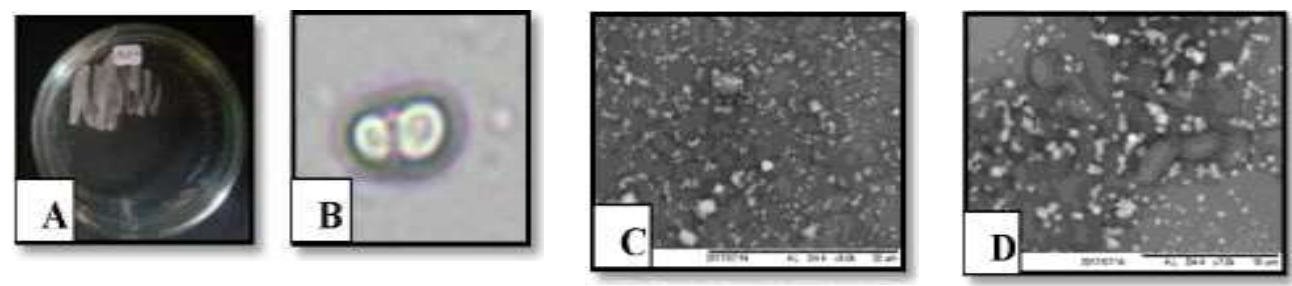

Figure 8. A) The growth of yeast in the YEPD solid media. B) The microscopic appearance of yeast in the electron microscope by 800 times magnification. C) microscopic appearance of yeast in SEM by 5000 times magnification. D) microscopic appearance of yeast in SEM by 7000 times magnification.

\section{MACROSKOPIC}

Based on the macroscopic observation indicate the beige color colony, convex elevation, has a soft texture, a blunt surface, and a flat colony edge. In the liquid medium P. Membranfaciens is aerobic caused by in liquid medium will form film layer or pellicle.

will form film layer or pellicle.

\section{MICROSKOPIC.}

Based on the microscope observation on the $P$. Membranfaciens has a size of $2.96 \mathrm{gm}$, the cells will continue to grow, the cell is egg-shaped and oval. The cell is single and paired. According to Hunsen (1904) subsequent to 3 days of inoculation in $25 \mathrm{oC}$ the yeast cell would be formed. The origin form of the yeast cell is ovoid-shape as egg and would be elongated, the size cell of $P$.

Membranfaciens is 1,8-4,5 x 2,5-7 gm. This yeast cell is generally single- celled andpaired to form small bundles. Reproduction is by the multilateral budding.

\section{JT4P"1 Cryptococcus wieringae}
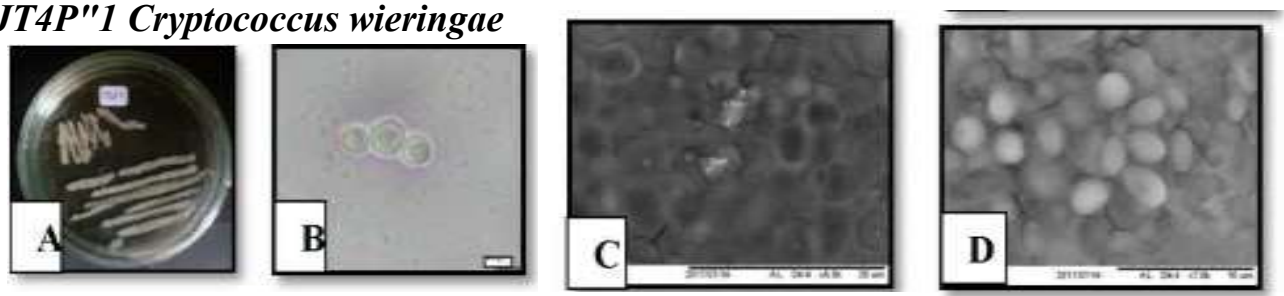

Figure 9. A) The growth of yeast in the YEPD solid media. B) The microscopic appearance of yeast in the electron microscope by 800 times magnification. C) microscopic appearance of yeast in SEM by 5000 times magnification. D) microscopic appearance of yeast in SEM by 7000 times magnification. 


\section{MACROSKOPIC}

Based on the macroscopic observation indicate the beige color colony, convex elevation, has a soft texture, a blunt surface, and a flat colony edge. In the liquid media $C$. wieringae is aerobic caused by in liquid medium will form film layer or pellicle.

\section{MICROSKOPIC.}

Based on the microscopic observations $\mathrm{C}$. wieringae has a size of $4.05 \mathrm{pm}$, the cells will continue to grow, the cell is egg-shape and the cell is single and paired.. According to Fanseca et al., (1970) subsequent to 3 days of inoculation at $25 \mathrm{oC}$ temperaturethe the cell grown in ellipsoidal shape with a size of 7.9-8.9 x 5.8-6.9 pm. Reproduction of yeast is by multilateral budding. This yeast habitat is in all parts of the plant.

Fungi isolation of the Straw

\section{Fusarium sp.}
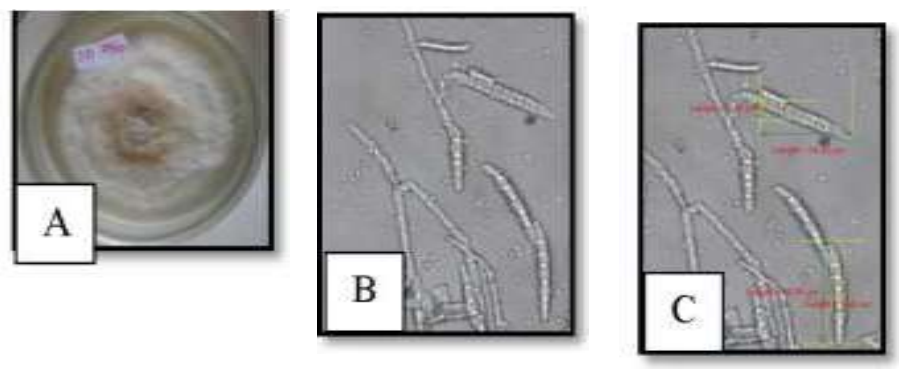

Figure 10. (A) Macroscopic appearance of fungi on the PDA growing media. (B) the microscopic appearance of the Fusarium spp fungi. (C) the microscopic appearance of the Fusarium spp fungi by the 400 times magnification.

\section{MACROSKOPIC}

The macroscopic appearance of petri dish seen in white color on the front part and peach color on the back part. The colony texture is rough, the distribution type is equally and evenly rounded, the colony collection seen as thick and has no concentric circle however the growing point is centered. The diameter size of fungi at one week is $8 \mathrm{~cm}$.

\section{MICROSKOPIC.}

Microscopic observation indicate that the hyphae is sectional, has hyaline color, conidiofor is in erect-shape, slender, the tip is narrowed. The hyaline color of Conidia is cylindrical shape with a blunt tip, have a bulkhead, the length is $34.93 \mathrm{pm}$ and the width is $7,85 \mathrm{pm}$. According to Campbell, 1996 hifa branching is cylindrical-shape, the conidia is be abundant. The Conidia size is $22-40 \times 3-4,5 \mathrm{pm}$. In one of conidia it has 3 to 5 bulkheads.

\section{Fusarium spp}
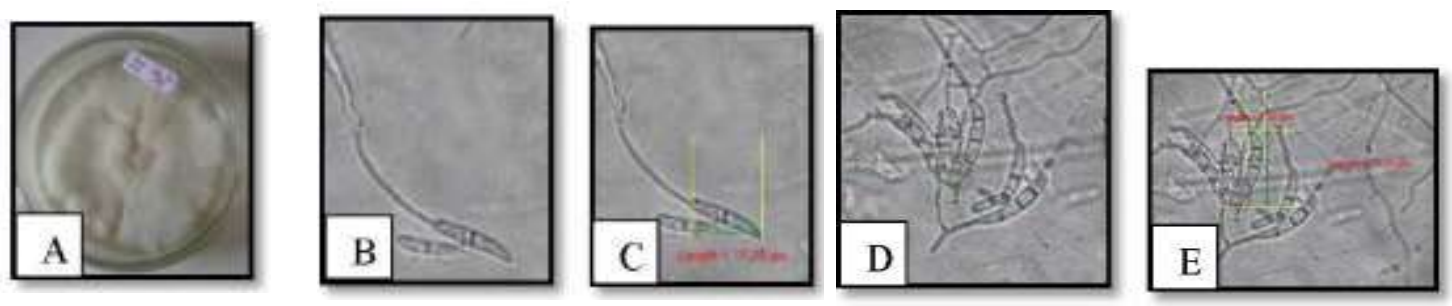

Figure 11. (A) macroscopic appearance of fungus on PDA media. (B) and (C) the microconidia microscopic appearance of single fusarium spp by the 400 times magnification. (D) and (E) the macroconidia microscopic appearance of Fusarium spp by the 400 times magnification. 


\section{MACROSKOPIC.}

The macroscopic appearance of petri dish seen in white color on the front part and peach color on the back part. The colony texture is rough, the distribution type is equally and evenly rounded, the colony collection seen as thick and has no concentric circle however the growing point is centered. The diameter size of fungi at one week is $8 \mathrm{~cm}$.

bulkheads. The Microconidia has 1728 x 2.5-4 size and consists of 1 to 2 bulkheads.

\section{MICROSKOPIC.}

Microscopic observation indicate that the hyphae is sectional, has hyaline color, conidiofor is in erect-shape, slender, the tip is narrowed. The hyaline color Conidia is cylindrical shape with a blunt tip, have a bulkhead, the length is $25,36 \mathrm{pm}$ and the width is $5,8 \mathrm{pm}$. According to Campbell, 1996 hifa branching is cylindrical-shape, the conidia is be abundant. The Macroconidia has $22-40 \times 3-4,5$ pm size. In one of conidia it has 3 to 5

\section{Trichoderma sp.}
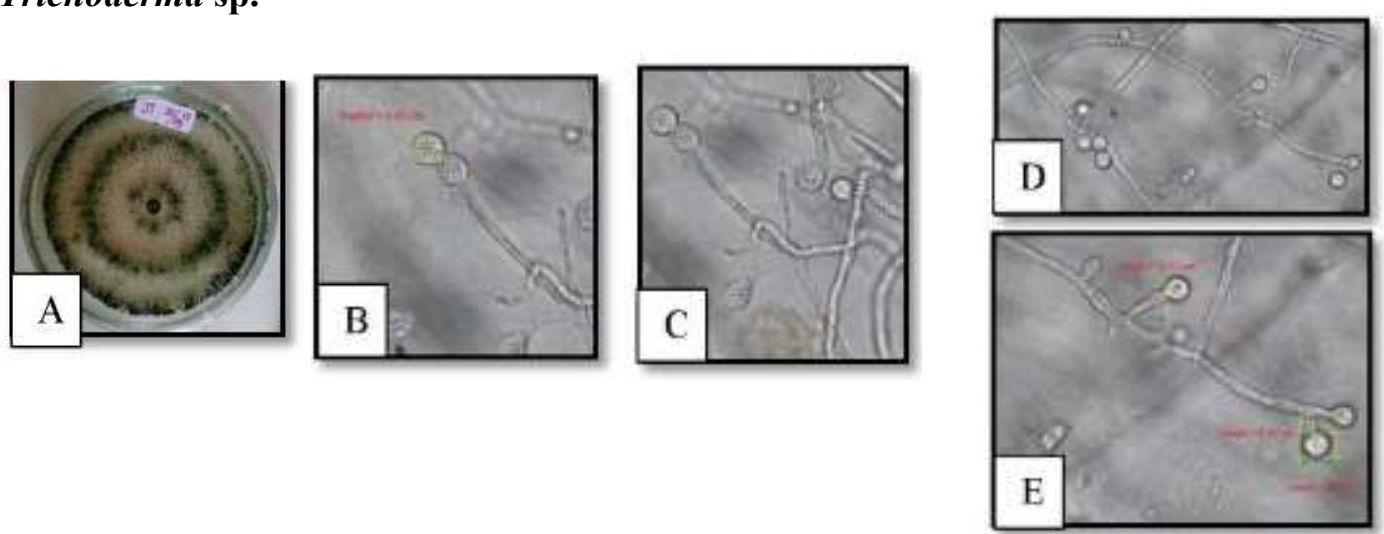

Figure 12. (A) Macroscopic appearance of Trichoderma sp fungi on the PDA growing medium. (B) (C) (D) (E) appearance of microscopic Trichoderma sp fungi in the microscope by 400 times magnification.

\section{MACROSKOPIC.}

The Trichoderma sp macroscopic appearance of on PDA growing medium seen in dark green color, forming a concentric circle, the distribution is equally to fill the petri dish, The texture is rough and grained. The diameter size of it at 7 days is $9 \mathrm{~cm}$. The colonies collection were thick and some of them were thin. The concentric circle formed has a thin texture

\section{MICROSKOPIC.}

The microscopic appearance of Trichoderma sp hifa is hyaline color, and the conidia is globoseshaped. The Conidia has no sectional. It has $8,45 \mathrm{pm}$ size and $12,54 \mathrm{pm}$ diameter. The conidiofor size is $12,13 \mathrm{pm}$. According to (Webster, 2007) Trichoderma sp

\subsection{The Yeast Variety}

The Variety analysis was obtained from the yeast isolation of straw namely, rice straw, maize straw, and cane straw. The yeast isolates of each straw is calculated by the number of colonies of each species in a petri dish. The isolation result provide the calculation data information by using the variety index $\left(\mathrm{H}^{\prime}\right)$. The results of the variety calculation is explained in Table 2. 
Table 2. The Calculation Result of $\mathbf{Y}$ (conidia is sticky and globose-shaped. There is Trichoderma sp in green and white color.

\begin{tabular}{llll}
\hline \multicolumn{1}{c}{ Straw types } & \multicolumn{2}{c}{ H' Calculation Result $^{\prime}$} & \multicolumn{1}{c}{ H' Value $^{*}$ Explanation } \\
\hline Rice Straw & 0,664391 & $3,0>\mathrm{H}^{\prime}<1,0$ & Low \\
\hline Maize Straw & 0,68929 & $3,0>\mathrm{H}^{\prime}<1,0$ & Low \\
\hline Cane Straw & 1,543782 & $3,0>\mathrm{H}^{\prime}>1,0$ & Medium \\
\hline
\end{tabular}

\section{Variety Index}

The variety index of rice straw is relatively low, the $\mathrm{H}$ ' calculation result that obtained from the rice straw is 0.664391 . In the maize straw it is also relatively low with the $\mathrm{H}^{\prime}$ calculation results is 0.68929 . However the variety index on the cane straw is relatively medium with the $\mathrm{H}$ ' result is 1.543782. The low and medium values in the variety index was influenced by various factors. One of the factor is the nutrients of the straw content.

According to the Agricultural Research and Development Center (2007) the rice straw is an organic material which is available in significant amounts for the rice farmers. Approximately $40 \%$ N, 30- 35\% P, 80-85\% K, and 40-50\% S. According to Suseno (1981) The nutrient content of the maize straw compost that is used in this research is in $2.52 \% \mathrm{~N}, 2.45 \% \mathrm{P}$ and $2.13 \% \mathrm{~K}$. According to Novizan (2002) in the Tyaswati (2005), the nutrient content in organic compost material is diverse depends on the material type that is used and the way of composting. Nutrient content of the compost such as: Nitrogen $0.1-0.6 \%$ : Phosphorus $0.1-4 \%$ : Potassium $0.8-1.5 \%$ : and Calcium $0.8-1.5 \%$. The organic material is an energy source and food sources for the microorganisms live in the soil. This is happen caused by the organic material provides carbon as an energy source for the growth of microorganisms (Doeswono, 1986).

\subsection{The yeast growth in SB Medium}

The yeast growth test on the SB medium indicate how the yeast works in utilizing the nutrients of the SB medium by fermentation and / or by the oxidation to produce energy. Oxidative yeast grows to form a wax layer (film) or pellicle on liquid growing, whereas fermentative yeasts usually grow throughout the liquid. The results test of the yeast growth in liquid medium is explained in table 3 .

\section{Table 3. Yeast growth in the liquid medium}

Yeast Isolate

The growth test in liquid medium

\begin{tabular}{ll}
\hline $\mathrm{JP}_{1} \mathrm{P}^{-4}$ (Candida parapsilosis) & Oxidative \\
\hline $\mathrm{JP}_{2} \mathrm{P}^{-5}$ (Bullera oryzae) & Oxidative \\
\hline $\mathrm{JJ}_{1} \mathrm{P}^{-1}$ (kluyveromyces termotolerant) & Oxidative \\
\hline $\mathrm{JJ}_{2} \mathrm{P}^{-5}$ (Candida tropicalis) & Oxidative \\
\hline $\mathrm{JT}_{1} \mathrm{P}^{-5}$ (Debaryomyces hansenii) & Oxidative \\
\hline $\mathrm{JT}_{2} \mathrm{P}^{-2}$ (Debaryomyces hansenii) & Oxidative \\
\hline $\mathrm{JT}_{2} \mathrm{P}^{-2}$ (Wickerhamomyces anomalus) & Oxidative \\
\hline $\mathrm{JT}_{3} \mathrm{P}^{-2}$ (Pichia membranfaciens) & Oxidative \\
\hline $\mathrm{JT}_{4} \mathrm{P}^{-1}$ (Cryptococcus wieringae) & Oxidative \\
\hline
\end{tabular}

Table 3 above indicate the yeast growth test in liquid medium tend to oxidative. No fermentative yeast found. The physical changes (color) at the sight of observation was not too visible yet the sediment and film layers seen clear. The oxidative yeast seen turbid. The change 
color in the liquid medium is also seen by the amount of sediment on the base of the media. The more sediment on the base of medium seen clearer, and vice versa the less of sediment on base of medium seen cloudy. According to Jumiyati et al., 2012 oxidative yeast on the SB medium shall form a media layer, while the fermentative yeasts form precipitates on the basic media. A strong oxidizing yeast is also capable to do fermentative, thus marked with a top film layer and a bottom sediment.

Table 4. Macroscopic Yeast Observation

\begin{tabular}{|c|c|c|c|c|c|c|c|c|c|}
\hline \multirow{3}{*}{$\begin{array}{r}\text { OBSERVATI } \\
\text { Amount }\end{array}$} & \multicolumn{2}{|c|}{ RICE STRAW ON } & \multirow{2}{*}{$\begin{array}{l}\text { MAIZE } \\
\text { STRAW } \\
J_{1} \mathrm{P}^{-1}\end{array}$} & \multicolumn{6}{|c|}{ CANE STRAW } \\
\hline & $\mathrm{JP}_{1} \mathrm{P}^{-4}$ & $\mathrm{JP}_{2} \mathrm{P}^{-5}$ & & $\mathrm{JJ}_{2} \mathrm{P}^{-5}$ & $\mathrm{JT}_{1} \mathrm{P}^{-5}$ & $\mathrm{JT}_{2} \mathrm{P}^{-2}$ & $\mathrm{JT}_{2}^{\prime} \mathrm{P}^{-2}$ & $2^{\mathrm{JT}_{3} \mathrm{P}^{-}}$ & $\begin{array}{l}\mathrm{JT}_{4} \mathrm{P}^{-} \\
1\end{array}$ \\
\hline & \multicolumn{2}{|c|}{193347} & \multicolumn{2}{|c|}{29794} & 291 & 314 & 226 & 179 & 285 \\
\hline Shape & Round & Round & $\begin{array}{l}\text { Roun } \\
d\end{array}$ & $\begin{array}{l}\text { Roun } \\
d\end{array}$ & Round & Round & Round & $\begin{array}{l}\text { Roun } \\
\text { d }\end{array}$ & $\begin{array}{l}\text { Roun } \\
\text { d }\end{array}$ \\
\hline Edge & Flat & Flat & Flat & Flat & $\begin{array}{l}\text { wavefor } \\
\mathrm{m}\end{array}$ & Flat & Flat & Flat & Flat \\
\hline Texture & smooth & Granules & 5 smooth & smooth & Granules & $\begin{array}{c}\text { Granul } \\
\text { es }\end{array}$ & $\begin{array}{l}\text { Granul } \\
\text { es }\end{array}$ & $\begin{array}{l}\text { smoot } \\
\mathrm{h}\end{array}$ & $\begin{array}{l}\text { smoot } \\
\mathrm{h}\end{array}$ \\
\hline Color & Beige & Beige & White & Beige & Beige & Beige & Beige & Beige & Beige \\
\hline Surface & Shiny & Shiny & Shiny & Shiny & Shiny & Shiny & Shiny & Shiny & Dull \\
\hline Elevation & $\begin{array}{l}\text { Konv } \\
\text { ex }\end{array}$ & $\begin{array}{l}\text { Conve } \\
x\end{array}$ & $\begin{array}{l}\text { Conve } \\
x\end{array}$ & $\begin{array}{l}\text { Conve } \\
x\end{array}$ & Convex & $x^{\text {Conve }}$ & $\begin{array}{l}\text { Conve } \\
\mathrm{x}\end{array}$ & $\begin{array}{l}\text { Conve } \\
x\end{array}$ & $\begin{array}{l}\text { Conve } \\
x\end{array}$ \\
\hline
\end{tabular}

\subsection{Nutrient Analysis}

Table 5. Initial Nutrient Content Analysis

\begin{tabular}{lcccrccc}
\hline Plant & $\begin{array}{c}\mathrm{C}- \\
\text { organiv }\end{array}$ & $\begin{array}{c}\mathrm{N} \\
\text { total }\end{array}$ & $\mathrm{C} / \mathrm{N}$ & $\begin{array}{c}\text { Organic } \\
\text { Material }\end{array}$ & $\mathrm{P}$ & $\mathrm{K}$ & $\mathrm{pH}$ \\
\hline Rice & 30,33 & 0,67 & 45 & 52,46 & 0,17 & 1,03 & 5,3 \\
\hline Maize & 33,99 & 0,71 & 48 & 58,79 & 0,07 & 0,85 & 6,0 \\
\hline Cane & 37,63 & 0,41 & 93 & 65,10 & 0,05 & 0,65 & 6,2 \\
\hline
\end{tabular}

According to the table 5 observation, the initial nutrient analysis or in advance of the rice straw decomposition process has an organic Carbon content for 30.33, Nitrogen content total for $0.67, \mathrm{C} / \mathrm{N}$ ratio comparison 45 , organic material content for 52,46, phosphate content 0.17 , potassium content 1.03, and has a $\mathrm{pH}$ of 5.3. The initial nutrient analysis or in advance of the maize straw has an organic Carbon content 33,39, total Nitrogen content of $0.71, \mathrm{C} / \mathrm{N}$ ratio comparison of 48 , organic material content 58.79 , phosphate content 0,07 , potassium content 85 and has a $\mathrm{pH}$ of 6.0. The initial nutrient analysis or before the decomposition process of rice straw has an organic Carbon content of 37.63, Nitrogen content total of $0.41, \mathrm{C} / \mathrm{N}$ ratio comparison 93, organic material content 65.10 , phosphate content 0.05 , potassium content 0,65 and has a $\mathrm{pH}$ of 6.2 . Straw has a nitrogen nutrient content ranged from 0.5 to 0.8 , phosphate nutrient content ranged from 1.16 to 0.27 , potassium nutrient content ranged from 1.4 to 2.0 in advance of it decomposed. The nutrient content be able to increase if the activators works actively as the decomposer of the organic fertilizer decomposition (Dobermann and Fairhurst, 2002) 
Table 6. Final Nutrient Content Analysis

\begin{tabular}{cccccccc}
\hline Plant & $\begin{array}{c}\text { C- } \\
\text { Organik }\end{array}$ & N total & C/N & $\begin{array}{l}\text { Organic } \\
\text { Material }\end{array}$ & & $\mathrm{K}$ & $\mathrm{pH}$ \\
\hline JT1P5 & 53,134 & 1,443 & 37,225 & 69,006 & 0,269 & 1,091 & 5,18 \\
\hline JT2P2 & 57,681 & 1,343 & 43,353 & 74,910 & 0,232 & 0,943 & 5,46 \\
\hline JT2'P2 & 58,391 & 1,386 & 42,697 & 75,883 & 0,245 & 0,995 & 5,32 \\
\hline JT3P2 & 55,731 & 1,428 & 39,447 & 72,378 & 0,282 & 1,145 & 5,05 \\
\hline JT4P1 & 52,747 & 1,510 & 34,922 & 68,503 & 0,293 & 1,194 & 5,78 \\
\hline JP1P4 & 59,222 & 1,328 & 44,869 & 76,912 & 0,275 & 1,117 & 5,7 \\
\hline JP2P5 & 55,403 & 1,443 & 38,837 & 71,952 & 0,280 & 1,135 & 5,75 \\
\hline JJ1P1 & 57,485 & 1,134 & 50,908 & 74,656 & 0,241 & 0,978 & 4,98 \\
\hline JJ2P5 & 51,241 & 1,466 & 34,312 & 66,547 & 0,307 & 1,244 & 5,6 \\
\hline
\end{tabular}

According to the table 6, each sample has an C-organic content and different organic material. RS (Rice Straw), CS (Cane Straw), MS (Maize Straw). Each straw was treated by adding the activator as the yeast decomposer. The result there was a change in the number of C-organic and the organic material compared in advance of adding the activator (table 5). In the table 6 the organic carbon value in JP1P4 and JP2P5 are 59,046 and 55,403 in succession. While the organic material content in JP1P4 and JP2P5 are 76,683 and 71,952 in succession. Compare to the initial Corganic value (table 5) there is a difference for 25.370 whereas the organic material is 24.639 . In the maize straw after yeast added, there is a change in the number of $\mathrm{C}$ - organic and the organic material compared in advance of adding the activator (table 5). In the table 6 the organic carbon value in JP2P5 are 56.269 and 50,296 in succession. Meanwhile the organic material content in JJ1P1 dan JJ2P5 are 73,076 and 65,319 in succession. Compare with the initial C- organic value (table 5) there is a difference for 23.170 and the organic material is

The table above categorized passably, yet the high $\mathrm{C} / \mathrm{N}$ ratio indicates that the compost is immature or not decomposed perfectly. Nitrogen, the $\mathrm{C} / \mathrm{N}$ ratio, $\mathrm{P}, \mathrm{K}$ is very high. The availability of 14.997. In the cane straw after the yeast added, there was a change in the number of C-organic and the organic material compared in advance of adding the activator (table 5). In the table 6 the organic carbon values in JT1P5, JT2P2, JT2'P2 ,JT3P2 dan JT4P1 are 53,134, 57,143, 58,391, 55,731 and 52,747 in succession. Whereas the organic material content in JT1P5, JT2P2, JT2'P2 ,JT3P2 dan JT4P1 are 69,009, 74,212, 75,833, 72,378 and 68,503. If it compared to the initial Corganic value (table 5) there is a difference for 21,328 , whereas the organic material is 10.823 .

\section{Table 7. Nutrient Content Criteria}

\begin{tabular}{|c|c|c|}
\hline Parameter Very Low & Low Medium High & Very High \\
\hline $\mathrm{C} \%$ & & V \\
\hline N\% & & V \\
\hline $\mathrm{C} / \mathrm{N} \%$ & & V \\
\hline P2O5\% & & V \\
\hline $\mathrm{K} 2 \mathrm{Cl} \%$ & & V \\
\hline
\end{tabular}

the nitrogen in high amounts due to the decomposition process by microorganisms. This nitrogen was obtained through 3 steps of reaction namely by the amine, ammonification, and nitrification reaction.

The amine reaction is the decomposition reaction of proteins in the organic material into amino acids. The ammonification reaction is the change of amino acids into ammonia compounds (NH3) and (NH4), and nitrification is the ammonia conversion become nitrite by involving the microorganisms. 
$\mathrm{P}$ element need plants to strengthen the roots. Deficiency of $\mathrm{P}$ element in the plant root caused the plant disrupted, and $\mathrm{P}$ also have a role in the photosynthesis process, metabolism and respiration (Cholik, 2003).

$\mathrm{K}$ element have a role in the plants assimilation process. The open and close mechanism of stomata was influenced by by the presence of $\mathrm{K}$ ions, while the stomata is open, it means the plants photosynthesis process will be proceed well, especially the $\mathrm{CO} 2$ fixation process that will produce asimilat to fill the plant life necessity.

The $\mathrm{pH}$ transformation occurs in all types of straw. The changes occurred were not so significant. The $\mathrm{pH}$ value was classified from acid to neutral. The yeast growing in almost of all acidity $(\mathrm{pH})$ degrees but the yeasts prefer to the acidic conditions. Most of the 4-6 $\mathrm{pH}$ tend to Sour and the temperature is $40 \mathrm{oC}$. The yeasts are able to adapt to various temperatures and the acidity conditions. According to Kurtzman (1998) yeast have a acidic $\mathrm{pH}$ tendency and a high content of organic material, compare to fungi and bacteria. The yeast able to grow in various $\mathrm{pH}$ ranges, but prefer to the acidic condition. In addition, yeast able to grow at the mesophilic temperature (25-40) and thermophilic $(>40)$.

\section{CONCLUSION}

By the research above it could be concluded that nine yeasts have found such as 2 yeast of the rice straw 2 yeast of the maize straw, and 5 yeast from the cane straw. Yeast in the rice straw, cane straw, and maize straw potentially as the organic fertilizer decomposer. The higher potential as the organic fertilizer decomposer is CS4P1 and the lower potentially yeast as the organic fertilizer decomposer is RS2P5. 


\section{REFERENCES}

Balai Penelitian dan Pengembangan Pertanian. 2007. Jerami Padi: Pengelolaan dan Pemanfaatan. Bogor.

Benson. 2001. Fifth Edition. Microbiological Aplication. Laboratory Manual in General Microbiology. The McGraw-Hills Companies.

Berkhout, C.M. 1923. De schimmelgeslachten Monilia, Oidium,Oospora en Torula. Thesis, University of Utrecht, TheNetherlands.

Cholik. 2003. Kualitas Unsur Hara Makro Kompos Bahan Baku Eceng Gondok ( Eichornia crassippes) Peranannya terhadap tanaman. Badan penelitian dan Pengembangan Kota Surabaya. Surabaya

Dobermann, A. and T. Fairhurst 2002, Nutrient Disorders and Nutrient management. Edisi Kedua. PPI- PPIC-IRRI. Los Banos, The philipines.

Jumiyati., S. H., I. Bintari, Mubarok. 2012. Isolasi dan identifikasi khamir secara morfologi di tanah kebun wisata pendidikan Universitas Negeri Semarang. Jurnal Biosaintifika 4 (1): 27-35

Husna, R., L.Sulistyowati, A. Muhibuddin. 2015. Eksplorasi Jamur dan Khamir pada Tanaman Cengkeh (Syzgium aromaticum) serta Uji Potensi Antagonismenya Terhadap Jamur Akar Putih (Rigidoporus microporus). Jurnal Hama Penyakit Tumbuhan 3(1). ISSN: 2338-4336.

Kurtzman, C.P., C.J. Robnett and E. Basehoar-Powers. 2008.Phylogenetic relationships among speciesof Pichia,Issatchenkia and Williopsis determined from multigenephylogenetic analysis, and the proposal of Barnettozymagen. nov., Lindnera gen. nov. And Wickerhamomyces gen.nov. FEMS Yeast Res. 8, 939954.

Langeron, M., and R.-V. Talice. 1932. Nouvelles methodes d'etude et essai de classification des champignons levuriformes.Ann. Parasitol. Hum. Comp. 10, 1-80.

Lodder, J., and N.J.W. Kreger-van Rij. 1952. The Yeasts, ATaxonomic Study. North-Holland, Amsterdam. Ludwig, JA, Reynold, JF. 1988. Statistical Ecology. A. Primer on Method on Competing: Jhon Willey and Sons.

Marvelia, A., D.Sri, P.Sarjana. 2006. Produksi tanman jagung manis yang diperlakukan dengan kompos kascing dengan dosis yang berbeda. Buletin anatomi dan fisiologis, Vol XIV. No 2, Oktober 2006.

Misra,R.V., R.N. Roy, H. Hiraoka. 2003. On - Farm Composting Methods. Rome: FAO. Land and Water Discussion Paper 2.

Muhibuddin, A., L. Adina, A.L.Abadi, A. Ahmad. 2011. Biodiversity of Soil Fungi on Integrated Pest Management Farming System. Agrivita 33(22): 111-118pp

Muhibuddin, A., I.R. Sastrahidayat. 2015. Soil Drive Nutrients Creation Through Alternate Host System Propagation of VAM to Support Selective Exploration of Microbial Fermentation. Brawijaya University. Malang.

Smith, R.L., 1980. Ecology and Field Biology. Harper \& Row Publishers New York. 835 p.

Subagio, V.D. 2010. Pengaruh pemberian dosis pupuk kompos sampah kota terhadap pertumbuhan dan hasil 5 varietas mawar (Rosa Hybrida, SP.) jurnal Departemen of Muhammadiyahmalang. http://student research.umm.id

Watanabe. T., L.H. Man, D.M .Vien, V.T. Khang, N.N. Ha, T.B. Linh, O. Ito. 2009. Effect of continuous rice straw compost application on rice yield and soil properties in the Mekong Delta. Soil Science and Plant Nutrition. 55:754-763.

Widrastutik, N.,N.H. Alami.2014. Analysis of Local Microorganism Solution Quality based on Gliogradia Sepium Leaves. Jurnal of Science and Pomirs Art 3(1) dalam Muhibuddin, A., N.U.Rizky, A.W. Sektiono, S. Nurhantika. 2016. Ethanol fermentation Potency of wild yeast on Bamboo Rhyzospher. Jurnal of Environmental Engineering and Suistanable Technology 3(2). University of Brawijaya Malang, Institute 